\title{
Role Model and Family Support Related to Self Efficacy Sleep in The Sand in Coastal Elderly
}

\section{Syaifurrahman Hidayat ${ }^{1}$, Mujib Hannan ${ }^{1}$}

1 Universitas Wiraraja Madura, Indonesia.

\section{Article Info}

Article History:
Submitted: May 9th 2021
Accepted: June 16th 2021
Published: June 23rd 2021
Keywords:
RoleModel, Family Support,
SelfEfficacy, Sleeping In
Sand, Coastal Elderly

\section{INTRODUCTION}

Elderlynaturally decreased physical and psychological functioning that can affect the ability of activities daily of the elderlyon the coast, the old process of becoming part of the process of life that occurred continuously which is generally experienced by all humans. ${ }^{1}$ The aging process is influenced by several factors such as genetics and the environment, where
Abstract

The elderly naturally experience a decrease in physical and psychological function so that it affects individuals in their daily activities. Self-efficacy is the ability to carry out a series of actions to provide life satisfaction for the elderly who sleep in the sand. Role models can provide role models for the elderly in doing activities to sleep in the sand where family support can influence the behavior of the elderly sleeping in the sand in the coastal elderly. The research method is descriptive-analytic with a cross-sectional approach. The population of this study were all the elderly who lived in the village, Village, Pasir Lenggung Batang Batang -District, Sumenep Regency as many as 124 elderly. The sampling technique used is purposive sampling. The analysis used is the test Spearman rank. The results of this study stated that most of the respondents had role models in the high category as many as $\mathbf{5 7 . 5 \%}$ coastal elderly, respondents had family support in the medium category as many as $72.5 \%$ coastal elderly, and respondents had self-efficacy sleeping in the sand in the capable category as many as $72,5 \%$ of coastal elderly. There is a relationship between the role model and the self-efficacy of sleeping in the sand in the coastal elderly and there is a relationship between family support and the self-efficacy of sleeping in the sand in the coastal elderly. Role models can be role models and motivations for the coastal elderly to sleep in the sand. When the role model is good, self-efficacy will increase, with that the ability of the elderly to carry out activities in the sand is better as well as the higher family support, the higher self-efficacy the elderly.

\section{Corresponding author:}

Syaifurrahman Hidayat

sr.hidayat@yahoo.com

South East Asia Nursing Research, Vol 3 No 2, June 2021

ISSN:2685-032X

DOI: https://doi.org/10.26714/seanr.3.2.2021.81-89

these factors affect cell metabolism which results in oxidative stress and causes damage to cells so that the aging process occurs. ${ }^{2,3}$

Feelings of being able or independent, not depending on others, being able to clean their own home are indicators of selfefficacy achieved by living alone. Self efficacy as an expectation of belief (hope) about how far individuals can carry out 
activities in certain situations. ${ }^{4}$ Self efficacy also determines individuals in carrying out certain behaviors, such as how strong individuals face difficulties and how these difficulties can affect individuals in the future. ${ }^{5}$

According to Pramudita \& Wiwien (2015) stated that self efficacy is a person's ability to move a series of activities needed so that they will get the goals to be achieved and finally can provide comfort to the elderly who sleep on the sand.

The need for sleep rest in the elderly is part of the life needs of each individual who has differences in sleep quality, health conditions and daily activities. Sleep needs for sick people are different from healthy people even though they are of the same age, which is caused by a sense of discomfort in the individual. ${ }^{7}$

The elderly population has increased from year to year, in Indonesia and even in the world the elderly population above 60 years is growing rapidly compared to other residents. As stated by the head of the Bengkulu province BKKBN representative, Widiati. Based on projections, in 2020, the number of elderly people is estimated to increase by 4.8 million people and will always increase to 9.8 million people in 2035. Based on the results of calculations and projections in 2020, the number of elderly people in Bengkulu will reach 260,000 souls. $^{8}$

Sumenep Regency is part of East Java Province which is located on the eastern tip of the island of Madura. The district has land areas and islands and has a variety of cultures. Its culture is related to food, art, and behavior. One of the villages named Legung Village, Batang-Batang District, Sumenep Regency has a community with a unique behavior tradition and is different from the surrounding villages. People who live in Legung are people who live on the coast who have specific and unique behavior. The elderly and their families in
Legung Village are synonymous with sand, which means that since ancient times until now, the Legung people have considered sand to be a necessity of life. ${ }^{9}$

Several factors affect self-efficacy among them the experience of a success (mastery experiences),the experience of others (vicarious experiences / social model of social persuasion,and physiological and emotional states. Factors affecting including role models, where role models can actually increase the interest of the elderly to choose the behavior of sleeping in the sand. Role models can be said to be parents, so the environment may be able to influence sleep behavior itself. ${ }^{10,11}$

Family support plays an important role in influencing the behavior of the elderly sleeping on the sand. The need for family support and attention occurs throughout life, so that if an elderly person does not get support they will feel inferior, restless, irritable and so on. By getting family support, the elderly will always feel cared for by their families. Family support can be shown by providing empathetic affection, giving advice, in sleeping behavior in the sand. ${ }^{12}$ Based on the background above, this research is interested in examining the relationship between role models and family support with self-efficacy sleeping in the sand in the coastal elderly.

\section{METHODS}

The type of this research is descriptive analytic with aapproach cross sectional. The population in this study were all the elderly living in the village Pasir Lenggang Batang Batang -District, Sumenep Regency, as many as 124 elderly, the sample in this study were some of the elderly livings in theVillage, Village Pasir Lenggung. sub-district, Sumenep Regency as many as 40 elderly and the sampling technique used is purposive sampling with inclusion criteria, namely the Batang-Batangelderly who live in the village of Legung Timur for more than 6 months, Ages 60 to 70 years, Elderly who 
has a sand bed at home, Elderly with experience of sleeping in the sand and respondents who are willing and willing, while the exclusion criteria are the elderly with bed rest or bed rest, the elderly with infectious diseases, the elderly who are not at the research location when data collection is at risk. This research was conducted in June 2021 in the Pasir Village, Lunggung Village, Batang-Batang Subdistrict, Sumenep Regency, Madura.The analysis used in this study is spearman rank to determine the relationship between variables with a significance level of $p<0.05$. namely the relationship between the role model and the self-efficacy of sleeping in the sand in the coastal elderly and the relationship between family support and the self-efficacy of sleeping in the sand in the coastal elderly.

\section{RESULTS}

Based on table 1 . states that most of the elderly are female as many as $32(80 \%)$ and male sex as many as 8 (20\%) elderly. Stating most respondents aged 64-69 years as many as $23(42.5 \%)$ and a small proportion of elderly aged 60-64 years as many as 17 $(42.5 \%)$. Most of the respondents with education level did not go to school as many as $23(42.5 \%)$ and a small proportion of elderly with the last education of junior high school or equivalent were $3(7.5 \%)$ elderly and states most of the respondents work status as housewives (IRT) as many as 32 $(42.5 \%)$ and a small number of elderly with work status as fishermen as many as 3 (7.5\%) elderly.

Based on table 2. states most respondents have a role models there are 23 (57.5\%)in the high category and a small proportion of the elderly have a role model in the category low as many as $4(10.0 \%)$ elderly, stated most respondents have support families in the moderate category as many as 29 $(72.5 \%)$ and a small proportion of the elderly with family support in the category low as many as $4(10.0 \%)$ elderly and It states that most respondents have Self efficacy sleeping in the sand in the capable category as many as 29 (72.5\%) and a small proportion of the elderly have Self efficacy sleeping in the sand in the category unable as many as $4(10.0 \%)$ elderly.

Based on table 3 states that most of the respondents with role models in the high category and having self-efficacy sleeping in the sand in the very capable category are 15 elderly (37.5\%) and a small proportion of respondents with role models in low category and have Self efficacy sleeping in the sand in the poor and unable category by $2(5.0 \%)$ elderly. Based on the results of statistical tests with Spearman's rho $=p$. value $0.009(<0.05)$ significantly stated that there was a relationship between the role model and the self-efficacy of sleeping on the sand in the coastal elderly and states that most respondents with family support are in the moderate category and have selfefficacy sleeping in the sand in the very capable category of 15 elderly (37.5\%) and a small proportion of respondents with family support at low category and have Self efficacy sleeping in the sand in the poor and unable category by $2(5.0 \%)$ elderly. Based on the results of statistical tests with Spearman's rho $=$ p. value $0.001 \quad(<0.05)$ significantly stated that there was a relationship between family support and self-efficacy sleeping on the sand in the coastal elderly.

Table 1

Distribution of respondents by sex, age, education level Education and Occupation

\begin{tabular}{|c|c|c|}
\hline Indicators & $\mathrm{f}$ & $\%$ \\
\hline \multicolumn{3}{|l|}{ Gender } \\
\hline Male & 8 & 20.0 \\
\hline Female & 32 & 80.0 \\
\hline \multicolumn{3}{|l|}{ Age } \\
\hline $60-64$ years & 17 & 42.5 \\
\hline 64-69 years & 23 & 57.5 \\
\hline \multicolumn{3}{|l|}{ Education level } \\
\hline Not in school & 23 & 57.5 \\
\hline Elementary school & 14 & 35.0 \\
\hline Junior high school & 3 & 7.5 \\
\hline \multicolumn{3}{|l|}{ Occupation } \\
\hline Housewife & 32 & 80.0 \\
\hline Farmer & 5 & 12.5 \\
\hline Fisherman & 3 & 7.5 \\
\hline
\end{tabular}


Table 2

Role model Respondent's, Family Support and Self efficacy sleeping in the sand

\begin{tabular}{lcc}
\hline \multicolumn{1}{c}{ Indicators } & $\mathrm{f}$ & $\%$ \\
\hline Role model & & \\
$\quad$ High & 23 & 57.5 \\
$\quad$ Enough & 13 & 32.5 \\
$\quad$ Low & 4 & 10.0 \\
Family Support & & \\
$\quad$ High & 7 & 17.5 \\
$\quad$ Medium & 29 & 72.5 \\
$\quad$ Low & 4 & 10.0 \\
Self efficacy sleeping in the sand & & \\
$\quad$ Very capable & 7 & 17.5 \\
$\quad$ Able & 29 & 72.5 \\
$\quad$ Unable & 4 & 10.0 \\
\hline
\end{tabular}

Table 3

Cross tabulation of role models with self efficacy in the elderly sleeping on the sand coast and Cross tabulation of family support with self-efficacy in the elderly sleeping on the sand coast Self-efficacy sleeping on the sand

\begin{tabular}{lccccccc}
\multicolumn{7}{c}{ Self-efficacy sleeping on the sand } \\
Variable & \multicolumn{2}{c}{$\begin{array}{l}\text { Very } \\
\text { capable }\end{array}$} & \multicolumn{2}{c}{ Able } & Unable & $p$ \\
& $\mathrm{f}$ & $\%$ & $\mathrm{f}$ & $\%$ & $\mathrm{f}$ & $\%$ & \\
\hline Role model & & & & & & & \\
$\quad$ High & 15 & 37.5 & 8 & 20.0 & 0 & 0.0 & \\
Medium & 6 & 15.0 & 7 & 17.5 & 0 & 0.0 & 0.009 \\
Low & 0 & 0.0 & 2 & 5.0 & 2 & 5.0 & \\
\hline Family support & & & & & & \\
High & 6 & 15.0 & 1 & 2.5 & 0 & 0.0 & \\
Medium & 15 & 37.5 & 14 & 35.0 & 0 & 0.0 & 0.001 \\
Low & 0 & 0.0 & 2 & 5.0 & 2 & 5,0 & \\
\hline
\end{tabular}

\section{DISCUSSION}

The results of the study stated that most of the respondents had role models in the high category as many as 23 (57.5\%) respondents had role models as role models in carrying out actions or sleeping activities on a sand bed, so that the activity of sleeping on the sand was carried out The elderly is a behavior that has been passed down from generation to generation by the people of the sand village who are trusted by the elderly.

According to Alexandrova (2018) states that watching other people perform a behavior and observing the consequences of their actions is assumed to increase people's confidence in their own ability to master similar tasks, with comparable results.
Incidents about other people's success or difficulties can be used as learning material or someone's role model to serve as an example in carrying out daily activities. ${ }^{14}$ Where this will affect individuals in carrying out activities similar to other people's experiences $^{15}$, the effects of other people's experiences depend on factors such as the observer's perception of the similarity between himself and the model, the number of model variations, the perceived strength of the model. , and the similarities between the problems faced by the observer and the model. The experience of others generally has a weaker effect on expectations selfefficacy than direct personal experience. ${ }^{16}$.

Role models are part of the self-concept of the elderly, it is also influenced by the level of maturity of the individual. Self-concept is formed in accordance with other people's assessment of him. ${ }^{17}$ Self-concept can occur due to the occurrence of activities that are passed with other people, learning from oneself through other people's mirrors can be used as part of a way of seeing oneself which is a self-interpretation of the views of others in sleeping activities. People who play a role in the daily life of the elderly can affect the culture and daily activities, namely by sleeping on the sand in the coastal elderly.

A small proportion of the elderly have a role model in the category low as $10.0 \%$ of the elderly, where education from the family is hereditary making the role model stronger and inspiring and motivating respondents to do activities sleeping in the sand and vice versa if education in the family in cultivating sleeping in the sand is not carried out it will reduce the role model more and more. low on family members. The behavior of imitating predecessors and culture plays an important role in the formation of role models because the thick culture adopted by the role models also makes the elderly follow or imitate these activities of sleeping in the sand. 
Someone's experience that has been done can serve as an example or role model for others, so that in carrying out an action or activity such as sleeping on the sand, people will believe that from their observations of the role model, it will also apply to the activities they do.

The results of the study stated that most of the respondents had family support in the moderate category as much as $72.5 \%$, where family support included providing instrumental support about sand bed facilities in the family having many benefits in a family, by supporting the elderly to sleeping on the sand can foster a sense of comfort in the family. Syaifurrahman Hidayat (2020) revealed the factors that influence the quality of life of the elderly, namely instrumental support, where this instrumental support is a factor that has a significant effect on the welfare of the elderly.

According to Santoso (2019) instrumental support is support in the form of real and material assistance. Material support from the closest people such as family, elderly friends in the vicinity, instrumental support can be in the form of housing, sand bed facilities, sand cleaning tools and so on which have become the daily lives of coastal elderly.

The results showed that a small proportion of the elderly with family support in the category is as low as $10.0 \%$ of the elderly, where the lack of emotional support from the family will affect the elderly self-defense mechanism is not adequate. The selfdefense mechanism of the elderly who are not strong in dealing with problems will cause prolonged stress and eventually symptoms of depression will arise. ${ }^{20}$ According to Stuart \& Laraia (2005) explains that emotional support can be given in the form of motivating the confidence of the elderly in dealing with the problems they face.
Sangian (2017) stated that family emotional support was in the $55 \%$ presentation. Among them the family can take the time to complete the needs of the elderly and provide a sense of empathy when needed by the elderly, so that with this the elderly can accept any changes that are experienced and live their lives well. ${ }^{22}$

Most of the respondents with the education level did not go to school as much as $42.5 \%$, which shows that there is a lack of exposure to information in the elderly. Elderly people with a lack of information from their families are due to the fact that the elderly are often at home and rarely gather with people around them. In addition, the answer is that the family does not remember about the benefits of sleeping on the sand in everyday life which is entrenched in the coastal elderly.(Hidayat, Mumpuningtias, et al., 2020) According to Clarkson (2020) assessment support is needed by the elderly such as special attention, positive appreciation so that the elderly feel recognized for their existence so that it is useful as a prevention of post power syndrome in the elderly.

The results of the study stated that most respondents had Self efficacy sleeping in the sand in the category capable of as much as $72.5 \%$, this indicates that the elderly are able to have self efficacy in sleeping on the sand such as. Basically, self-efficacy is based on a strong belief in the role model carried out by their previous predecessors.

Self efficacy is an individual's belief in actions or activities in achieving goals that are part of daily activities, Self Efficacy can have an impact on thinking patterns and can motivate oneself in behavior. ${ }^{24}$

Albert Bandura (1986) in Christianity describes the importance of self-efficacy as a belief that serves as "an important set of proximal determinants of human motivation, influence, and action". This belief is a form of activity or action that provides cognitive and affective 
encouragement, as well as cognitive processes related to setting personal goals, the higher the level of perceived selfefficacy, the better the level of one's goals, leading to a higher level of commitment to goals. ${ }^{26}$

Anisa (2018) states the formation of selfefficacy which is believed by local people to maintain this unique habit by passing down the sand mattress tradition informally. Parents socialize this sand bed culture through habits that are carried out continuously at home, so that children can see, and be involved in the habits of their parents. In addition, village officials who also play an important role in determining the policies taken in the areas they lead relate to sand beds, village officials are basically aware of the interest of people outside the village to the uniqueness of this sand bed village. So when observing from children to the elderly how the role models carry out activities on the sand bed, the increase in self-efficacy also occurs when the respondents believe in the hereditary traditions of their families.

The results of the study show that a small proportion of the elderly with self-efficacy sleep in the sand in the category unable as much as $10.0 \%$ of the elderly, where selfefficacy in someone other than obtained from life experience is also determined by errors in self-assessment, if in daily activities by sleeping on the sand becomes part of a positive activity, then self-efficacy in individuals it will be good too, and vice versa if in daily activities sleeping in the sand is part of an activity that has a bad impact on a person then self-efficacy will deteriorate in the individual. Events from past experiences will be part of learning in determining self-efficacy through cognitive representations including memory of the frequency of distress and difficulty. ${ }^{28,29}$

When self-efficacy increases, the ability to solve problems or the ability to do tasks in the elderly will also increase. The results of observations on success can motivate an increase in self-efficacy in respondents so that it can also increase success in carrying out various activities to sleep in the sand.

The results of the study stated that most of the respondents with role models in the high category and having Self efficacy sleeping in the sand in the very capable category of $37.5 \%$ and based on the results of statistical tests with the test Spearman's rho $=0.009(<0.05)$ significantly states that there is a relationship between role models and self-efficacy sleeping in the sand in the coastal elderly, where according to Zulkosky (2009) self-efficacy will increase when people see other people doing tasks and feel confident that they can complete the same task successfully with favorable results. This is especially true if the observer assumes the model has the same capabilities. From the results of this study, it can be said that the role model has a relationship in self-efficacy in respondents.

This research is in line with research Sadewi (2012) where increasing self-efficacy when observing role models, not only observations but also the success of the role model which also increases the self-efficacy of respondents who have thoughts when the role model is successful, I will also managed to do so. ${ }^{30}$

Role models are a powerful source of beliefs self-efficacy because they provide observers with the strategies and techniques needed to achieve desired goals. Several correlational studies have measured representative experiences and investigated their relationship to health behaviors. ${ }^{13}$

Role models, when included as part of an intervention, have been shown to effectively increase health behavior-specific selfefficacy. In a study examining the effects of vicarious experience, mastery experience, and verbal persuasion on self-efficacy, vicarious experience was found behind mastery experience to be the second 
strongest predictor of self-efficacy. qualitative study. ${ }^{13}$

Basically, the elderly follow the activities that have been carried out by their ancestors and some beliefs that increase self-efficacy also play an important role in imitating role models, for example role model beliefs in healing several diseases that can be cured by sleeping in the sand.

Self-efficacy beliefs are representative experiences, or models. Watching others perform a behavior and observing the consequences of their actions is assumed to increase people's confidence in their own ability to master similar tasks, with comparable results. Vicarious experiences are a powerful source of beliefs self-efficacy because they provide observers with the strategies and techniques needed to achieve desired goals.(Wanner et al., 2011)

When self-efficacy increases, the respondent's ability to perform a task or an activity will be done better than respondents with low self-efficacy. Role models can be role models and motivations for respondents in doing activities sleeping in the sand. The success of the role model will be a motivation for the respondents. Starting from observing the success of this role model, respondents will experience an increase in self-efficacy.

The results of the study stated that the majority of respondents with family support in the moderate category and having Self-efficacy sleeping on the sand in the very capable category of $37.5 \%$ and based on the results of statistical tests using the test Spearman's rho $=0.001(<0.05)$ significantly states that there is a relationship between family support and self-efficacy of sleeping in the sand in the coastal elderly, where the higher the family support, the higher the self-efficacy of the elderly. Meanwhile, the lower the family support, the lower the self-efficacy of the teenager. ${ }^{32}$
Family support in this case is a motivation in the form of social persuasion by the family that affects the self-efficacy of the elderly. According to Bandura (1986) individuals who are directed by guidance can improve their abilities so that they can support someone to achieve their desires. Social persuasion will be effective if the persuasion is carried out by the closest person who is trusted by the person.

Sitanggang (2021)stated that health problems experienced by the elderly require advocacy where the elderly need support for several issues both from their families,caregivers, other professionals, and orphanages. This support can encourage the elderly to give hope, feelings, and rejection.

According to Ayuni (2020) stated that family support plays an important role in providing sec motivation Physical and psychological means where the family has various functions such as informational support consisting of advice, suggestions, advice, instructions and information providers. Assessment support which involves providing information, advice or feedback from the family to the elderly who face certain situations and conditions. Instrumental support can be provided by helping the elderly directly, in terms of food, drink, and rest needs to avoid fatigue and emotional support which is manifested in the form of affection, trust and attention. ${ }^{12}$

High family support because the supportive environment, especially the family, plays a very important role in the process of sleeping in the sand on a daily basis, this is because the elderly rarely have the will that comes from themselves, most of them come from other people or family, so there are many forms of support. Family needs that need to be given to the elderly include emotional support, rewards, material and information about the benefits of sleeping in the sand. ${ }^{35}$

The orientation of self-control is part of the factors that affect self-efficacy, where if 
someone is in the orientation of internal control, it will lead to the achievement of the desired goals. Self-efficacy shows feelings in the elderly that he believes in the benefits of sleeping on the sand can provide benefits for health and comfort for the elderly, selfcontrol orientation is internal so that it can have a positive self-efficacy impact by illustrating that the elderly will try to solve their own problems in carrying out activities everyday by sleeping on the sand. ${ }^{36}$

\section{CONCLUSION}

Most respondents have role models in the high category as many as $57.5 \%$ coastal elderly, Most respondents have family support in the moderate category as many as $72.5 \%$ coastal elderly, most of the respondents have Self efficacy sleeping in the sand in the capable category as much as $72.5 \%$ coastal elderly and There is a relationship between role models and selfefficacy sleeping in the sand in the coastal elderly and there is a relationship between family support and self-efficacy sleeping in the sand in the coastal elderly

\section{ACKNOWLEDGMENTS}

Thank you to the Chancellor of Wiraraja University and LPPM Wiraraja University for the facilities that funded this research activity based on the University's Internal Fund Research Contract for Fiscal Year 2021 Number: 052 /SP2H/PENDI/LPPM/UNIJA/V/2021 and Thank you to the Sumenep District Health Office, especially for theHealth Lenggung Center who has been willing to give us permission to conduct this research.

\section{CONFLICTS OF INTEREST}

Neither of the authors has any conflicts of interest that would bias the findings presented here.

\section{REFERENCES}

1. Hidayat S. Dhikr Khafi to Reduce Osteoarthritis Pain Scale in the Elderly. J Heal Sci. 2014;1(1):13-22.

2. Bhattarai P, Newton-John TRO, Phillips JL. Apps for pain self-management of older people's arthritic pain, one size doesn't fit all: A qualitative study. Arch Gerontol Geriatr. 2020 Jul;89(March):104062.

3. Hidayat S, Mumpuningtias ED, Indriyani R. The Combination Therapy of Self-Surrender Exercise and Distraction Against Osteoarthritis Pain Scale of Elderly In Coastal Area. Str J Ilm Kesehat. 2020 Nov;9(2):1212-22.

4. Bandura A. Self-efficacy: Toward a Unifying Theory of Behavioral Change. Psychol Rev. 1977;84(2):191-215.

5. Friedman M. Family Nursing: Theory and Practice. Interpreting, Ina DRL., Yoakim A, Editor, Yasmin A., Setiawan, Monica E., Edition 3. Jakarta: EGC; 2008.

6. Pramudita, Wiwien A. A total of 36 million people worldwide live in orphanages. 2015.

7. Hidayat S, Mumpuningtias ED. Pendampingan Keluarga Dan Perawatan Orang Dengan Gangguan Jiwa Bebas Pasung. JAPI (Jurnal Akses Pengabdi Indones. 2018 Dec;3(2):65.

8. Hidayat S. Klenengan Music Therapy on Sleep Quality in Elderly Patients at Pratama Barokah Clinic. J Med Sci Clin Res. 2018 Dec;6(12).

9. Mulyadi E, DIP. Behavior, Support System, and Daily Habits of the Kampung Pasir Indigenous People. Kendal Coll Heal Sci J Nurs. 2021;13(1):183-190.

10. Lenz E, Shortridge L. Self Efficacy In Nursing. New York: Springer Publishing Company; 2002.

11. Lestari A, Hartati N. Relationship of Self Efficacy with Subjective Well Being in Elderly Living at Home Alone. J RAP UNP. 2016;7(1):15.

12. Oktaviana R, Hidayat S, Dwi M. The Role of the Family on the Cognitive Function of the Elderly in Pandian Village, Sumenep Regency. J Heal Sci. 2019;4(2):13-9.

13. Alexandrova E, Shapekova, NL, AK B, Ozcanaslan R. Health Sciences Research in The Globalizing World. Turkey: ST Kliment Ohridski University Press Sofia; 2018.

14. Putri H, Muqodas I. Approach ConcretePictorial Abstract (CPA), Mathematical Anxiety, Mathematical Self Efficacy, Instruments and Learning Designs. Sumedang: UPI Sumedang Press; 2019.

15. Manuntung A. Cognitive Behavioral Therapy in 
Hypertensive Patients. Malang: Wineka Medika; 2018.

16. Maddux J. Self Efficacy, Adaptation, and Adjustment: Theory Research and Application. New York: Springer Science \& Business Media.; 2013.

17. Stuart G, Laraia M. Principles and Practice of Psychiatric Nursing, 8th edition. St. Louis: Mosby Book Inc.; 2005.

18. Hidayat S, Hannan M, Mulyadi E. The Effectiveness of Self-Surrender Exercise and Dzikir Therapy in Improving the Quality of Sleep in A Nursing Home in Pasuruan, Indonesia Road. Int J Psychosoc Rehabil. 2020 Feb;24(4):5188-97.

19. Santoso M. Quality of Life for the Elderly: Review Article. J Mesencephalon Heal. 2019;5(1):33-41.

20. Hidayat S, Mumpuningtias ED. Terapi Kombinasi Sugesti Dan Dzikir Dalam Peningkatan Kualitas Tidur Pasien. Care J Ilm Ilmu Kesehat. 2018;6(3):219.

21. Sangian LM, Wowiling F, Malara R. Hubungan Dukungan Emosional Keluarga Dengan Penerimaan Diri Pada Lansia Di Desa Watutumou III. J KEPERAWATAN. 2017;5(2):18.

22. Hannan M, Hidayat S. The Role of Families in Caring for Patients with Pulmonary Tuberculosis in Gapura District, Sumenep Regency. MKM. 2013;2(1).

23. Clarkson TR, Sidari MJ, Sains R, Alexander M, Harrison M, Mefodeva V, et al. A multivariate analysis of women's mating strategies and sexual selection on men's facial morphology. R Soc open Sci. 2020;7(1):191-209.

24. Oktarianti, Irawan E, Amelia F. Relationship of Self Efficacy with Hypertension Elderly Self Care. BSI J Nurs. 2017;5(2):4-7.

25. Bandura A. Social Foundations of Thought and Action: a Social Cognitive Theory. New Jersey:
Prentice_Hall, Inc.; 1986.

26. Zulkosky K. Self Efficacy: A Concept Analysis. ResearchGate. In: Nursing forum. 2009. p. 93102.

27. Anisa U. Melestarikan Tradisi Lokal : Kampung Kasur Pasir. J Sej dan Budaya. 2018;7(1).

28. Rustika I. Self-Efficacy: An Overview of Albert Bandura's Theory. Psychology Bulletin Universitas Gadjah Mada. 2012;1-4.

29. Hannan M, Hidayat S, Fatoni A. The Effect of Blood Pressure On The Quality of Daily Sleep In The Elderly In PSTW Pandaan. Str Sci J Heal. 2021;10(1):1201-6.

30. Sadewi A, Sugiharto D, Nusantoro E. Improving Self Efficacy in Mathematics Learning Through Content Mastery Services with Symbolic Modeling Techniques. Indones J Guid Couns Theory Appl. 2012;8.

31. M. Wanner L, Schuz B, Knittle K, P. Ziegelmann J, Wurm S. Sources of Perceived Self Efficacy as Predictions of Physical Activity in Older Adults. Int Assoc Appl Psychol. 2011;1-21.

32. Widanarti N, Indati A. The Relationship BetweenSocial Support FamilyWith Self Efficacy In Adolescents At Sma Negeri 9 Yogyakarta. J Psychol. 2002;2(1):112 - 123

33. Sitanggang $\mathrm{Y}$, Frisca $\mathrm{S}$, Sihombing $\mathrm{R}$, Koerniawan D, Tahulending P, Febriana C, et al. Gerontic Nursing (1st ed.). Our Writing Foundation; 2021.

34. Ayuni D. Textbook of Nursing Care in Post Cataract Surgery Patients. Independent Gallery library; 2020.

35. Yunitasari I. Hubungan Dukungan Keluarga dan Self-Efficacy Dengan Upaya Pencegahan Relapse Pada Penyalahguna NAPZA Pasca Rehabilitasi. Psikoborneo J Ilm Psikol. 2018;6(2).

36. Raharjayanti Y. Dukungan Sosial Keluarga dan Self Efficacy Siswa SMP dalam Menghadapi Ujian Nasional. J PROMKES. 2019 Dec;7(2):133. 